Черешнюк Г.С., Комарницька Н.Т.

\title{
Інноваційні технології в до- і післядипломній підготовці керівників закладів охорони здоров'я і лікарів-інтернів на кафедрі соціальної медицини та організації охорони здоров'я
}

Вінницький національний медичний університет імені М.І. Пирогова, м. Вінниця, Україна

galinamakeeva47@ukr.net, natakomarvinmed@gmail.com

\author{
Черешнюк Г.С., Комарницкая Н.Т. \\ Инновационные технологии в до- и последипломной \\ подготовке руководителей учреждений \\ здравоохранения и врачей-интернов на кафедре \\ социальной медицины и организации \\ здравоохранения
}

Винницкий национальный медицинский университет имени Н.И. Пирогова, г. Винница, Украина

\author{
Chereshnyuk G.S., Komarnitska N.T. \\ Innovative technologies in pre- and postgraduate training \\ health care executives and interns at the Department \\ of social medicine and organization of health care \\ National Pirogov Memorial Medical University, \\ Vinnytsya, Ukraine
}

\section{Вступ}

Радикальні зміни в національній системі охорони здоров'я, які набирають обертів на сучасному етапі іiі розвитку потребують відповідної перебудови в допіслядипломній освіті лікарів. У Вінницькому національному університеті ім. М.І. Пирогова (ВНМУ), враховуючи нові підходи до безперервної післядипломної освіти та беручи до уваги міжнародний досвід, активно запроваджуються навчально-методичні інновації.

Першим напрямом цієї роботи стало підвищення професійного рівня викладачів кафедри після конкурсного відбору, що здійснювався американськими експертами. Вони отримали можливість пройти 5-ти тижневе стажування у School of Public Health Бірмінгемського університету у штаті Алабама (UAB), США. Продовженням цього стажування стало навчання у Зимових школах, що проводилися спеціалістами UAB та ВНМУ на базі нашого університету. Це дозволило ознайомитись 3 сучасною методикою навчання і запровадити нові інтерактивні форми навчання в розділах: «Стратегічний менеджмент», «Психологія управління», «Фінансовий менеджмент».

Ще одним шляхом отримання викладачами i керівниками охорони здоров'я сучасних знань у галузі управління $€$ участь у Літніх школах за тематикою «Трансформація систем охорони здоров'я у Східній Європі» і Зимових школах, присвячених проблемам громадського здоров'я в Україні і Світі. Робота цих шкіл $є$ міжнародним проектом із залученням експертів світового рівня 3 Великої Британії, Нідерландів, Німеччини, Швейцарії, Хорватії, Ізраїлю, Литви, представників МO3 України і засобів масової інформації. Підтримку цієї програми здійснюють Світовий Банк USAID Swiss Cooperation Office Ukraine i UNICEF.
Підготовка лікарів-інтернів всіх спеціальностей у сучасних умовах потребує розширення кола знань у галузі управління охороною здоров'я, зокрема проведення реформ, завдяки яким повинна підвищитись якість, доступність надання медичної допомоги на первинному, вторинному i третинному рівнях. Завдання кафедри соціальної медицини та організації охорони здоров'я сформувати системні знання у лікарів-інтернів стосовно їх спеціальності i розуміння взаємозв'язку первинної медичної допомоги 3 вторинною спеціалізованою i третинною високоспеціалізованою, високотехнологічною медичною допомогою.

Не реформована до кінця вітчизняна система управління медичною галуззю на різних рівнях іноді гальмує ініціативу, і щоб «розтопити кригу» потрібно залучати в процес реформ не лише професіоналів медиків, a i молодих фахівців, якими завтра стануть теперішні лікарі-інтерни.

Сьогодні населення держави i лікарі чекають кардинальних змін, тому що попит на реформи у суспільстві вже сформовано. Враховуючи інтереси сьогоднішніх комунальних некомерційних підприємств (КНП) і медичних вишів, потрібно надати реформам необхідний позитивний імпульс. Натомість ми бачимо інші реалії: майбутні лікарі воліють мовчати, побоюючись висловлювати свої думки, але, набувши сучасний рівень знань, вони стануть набагато сміливішими в реалізації своїх новаторських ідей. Важливою умовою до того ж, є відчуття підтримки не лише на рівні викладачів вищих навчальних закладів (ВН3), а і держави в цілому.

Як свідчить практичний досвід, реформуванню галузі повинно передувати обговорення широкого кола питань. Хто має стати рушійною силою в медицині? 
Звичайно, насамперед - вищі медичні навчальні і наукові заклади країни.

Сьогодні назріла нагальна потреба в децентралізації медичної освіти, тому що новий Закон України «Про вищу освіту» дав університетам певну свободу дій. Безумовно, одним з основних завдань реформи медичної галузі має стати професіоналізм і довіра пацієнта до лікаря.

\section{Матеріали та методи}

Наш університет став співучасником проекту «BIHSENA» - «Поєднання Інновацій, Здоров'я i Суспільств: освітній розвиток потенціалу в сусідніх районах Східної Європи», очолюваного Маастрихтським університетом (Нідерланди), в рамках якого на стажуванні викладачі опанували методику використання проблемноорієнтованого навчання (ПОН). До складу учасників проекту, крім організаторів-викладачів університету із Нідерландів, входили фахівці із України (ВНМУ, КиєвоМогилянська академія), Польщі, Болгарії, Росії. Проект був співфінансований програмою «Еrasmus+» Європейського Союзу (ця публікація відображає лише погляди авторів на дану проблему. Свропейська комісія не несе відповідальності за ії зміст).

Згідно вимог проекту із застосуванням ПОН, було розроблено 2 тематичні курси «Управління якістю медичних послуг» і «Фінансовий менеджмент в охороні здоров'я».

Процес використання ПОН відбувається наступними чином:

Заняття проводяться 2-3 рази на тиждень в групах до 10 учасників. Вирішення проблемного питання складається 37 кроків:

Крок 1. Групі пропонується проблемна ситуація, яку необхідно «вирішити». В якості стимулюючого елементу використовують «тригери», включені в спеціальні «кейси», що спрямовують учасників спочатку до формулювання переліку питань, які допоможуть їм самостійно здобути знання з даної теми, а потім розробити альтернативи вирішення ситуації. Самостійно, між одногрупниками розділяються ролі: лідер групи; особи, що відповідають за пошук інформації; іiі обробку; презентацію результатів. Ролі в групі змінюються при вирішенні кожної наступної ситуації для того, щоб виробити у учасників різні навички. Всі повинні стати учасниками активного процесу пошуку, засвоєння знань $\mathrm{i}$ їх підсумовування.

Крок 2. Учасники групи в процесі дискусії мають чітко визначити та зрозуміти суть проблеми, запропонованої в завданні, адже вона не завжди однозначна і очевидна.

Крок 3. Фаза «Мозкового штурму» - широке, вільне обговорення, вислів ідей, аналіз узгодженої теми. На цьому етапі учасники визначають, які знання у них вже надбані, завдяки власному досвіду і раніше опанованим темам, а яку додаткову інформацію ще необхідно здобути для успішного вирішення завдання.
Крок 4. Широкий обмін отриманою інформацією, відповідно до виконуваних учасниками ролей, узгодження незрозумілих питань, розробка попередніх висновків.

Крок 5. Пошук можливих шляхів оптимального вирішення проблемної ситуації 3 урахуванням запропонованих учасниками альтернатив.

Крок 6. Обговорення та формулювання навчальних цілей. На цьому етапі підключається викладач - до цього він лише спостерігав за самостійною роботою групи. Тепер він має переконатись, що поставлені цілі $\epsilon$ досяжними, спрямованими, повними та відповідними до курсу загалом. Спільно визначається ціль подальшої роботи групи.

Крок 7. Підготовка презентації і представлення іï викладачу. На цьому занятті викладач може застосовувати різні критерії оцінки знань.

Методика ПОН пройшла тестування в двох групах учасників - слухачів курсів післядипломної підготовки, організаторів охорони здоров'я, яким було запропоновано 2 спеціально підготовлені проблеми 3 практики діяльності медичних закладів Вінницької області. Ми отримали цікаві схвальні відгуки від учасників тестування. Було зазначено, що цей підхід змусив їх задля того, щоб відповідати власному авторитету і статусу, пересвідчитися у власному умінні вирішувати певні проблеми, які існують в роботі кожного управлінця, зуміти оцінити переваги роботи в команді та важливість правильного розподілу завдань, налагодити позитивні комунікації в групі, абстрагуючись від поточних обставин, сконцентруватись на вирішенні стратегічних проблем, залучити свої знання і досвід, проявити творчість, активність, звернутись до різних джерел інформації, включно з мережею Інтернет та бібліотечними ресурсами. Серед можливих проблем широкої імплементації цього методу в начальний процес слід зазначити потребу в спеціально підготовленому, високопрофесійному викладацькому персоналу, складності при самостійному пошуку джерел інформації, брак знань іноземних мов.

Підготовка лікарів-інтернів різних спеціальностей на кафедрі соціальної медицини та організації охорони здоров'я доповнена нами вивченням їх думки стосовно Законів України про: охорону здоров'я, вищу освіту, реформування медичної галузі, а також позитивними i проблемними моментами в проведенні реформ. Обговорення з інтернами здійснюється різними методами. Особливу зацікавленість викликають заняття на основі «Техніки номінальної групи» (Nominal Group Technik NGT) по американській методиці, якою ми оволоділи, навчаючись у Літньому інституті (м. Бірмінгем, штат Алабама, США).

Метод NGT, який ще називають методом Дельфі, був розроблений в 1975 р. дослідниками робочого планування для груп експертів Ендрю Дельбеком, Ендрю Ван де Веном та Девідом Гювстафсоном в Університеті Мінесоти, США. В 90-х роках метод був адаптований для медичної галузі і впроваджений Річардом Шучаком та Робертом Хернадесом (Університет Алабама, Бірмінгем, США). 
Мета проведення тренінгу за цим методом: вияснити проблеми в підготовці майбутніх медичних кадрів на рівні ВН3 і напрямки покращення якості навчання молодих лікарів в інтернатурі.

Які переваги «Техніки номінальної групи»?

1. Продукується велика кількість практичноорієнтованих ідей.

2. $€$ можливість оцінити вагомість ідей.

3. Даються рівні можливості для голосування.

4. Виключається прийняття поспішного рішення.

5. Високий свідомий рівень виконання завдань.

6. Зацікавленість в кінцевому результаті.

7. Колегіальність в прийнятті рішень. групи»?

В чому суть проведення «Техніки номінальної

Крок 1. Викладач формулює проблему. Наприклад: «Які заходи потрібно впровадити у медичному ВНЗ, щоб покращити підготовку лікарів-інтернів?»

Крок 2. Проводиться генерація ідей інтернами індивідуально в письмовому вигляді.

Крок 3. Здійснюється запис ідей кожного учасника тренінгу та їх поетапне висловлювання. Записи ідей інтернів проводяться швидко і в оригіналі, без коментарів викладача, тому що це $\epsilon$ обов'язковою вимогою тренінгу.

Крок 4. По закінченню озвучення ідей весь їх перелік має стати доступним для кожного учасника.

Крок 5. Викладач просить групу із всіх ідей вибрати певну кількість (за певним критерієм, наприклад - три самих важливих, або самих актуальних, або дуже складних, які складно виконати).

Крок 6. Далі кожна ідея особисто занотовується на окрему картку (розміром $3 \times 5$ см) або стікер, які не підписуються учасником.

Крок 7. Кожна ідея оцінюється самим учасником 3 використанням бальної системи (3, 2, 1 бали) і маркується.

Крок 8. Викладач збирає картки, перетасовує їх для збереження анонімності.

Крок 9. Проводиться підрахунок балів згідно переліку ідей, а отримані результати записуються на великому плакаті перед учасниками групи.

Крок 10. В кінці підводяться підсумки по рейтингу ідей і отримані результати обговорюються.

Результати тренінгу дозволяють визначити основну тенденцію в думках учасників - виявити ключові проблеми і в подальшому працювати над їх вирішенням. Ці висновки обговорюються на засіданнях кафедри.

Важливо зрозуміти, що майбутній лікар, навчаючись у медичному ВНЗ має відчути внутрішнє покликання до цієї дуже відповідальної і надзвичайно важливої професії, саме тому необхідним є високий рівень не лише професійної підготовки лікаря, а і його свідоме ставлення до проблем у галузі.

Загалом були залучені 96 лікарів-інтернів зі спеціальностей: хірургія, неврологія, травматологія, терапія, загальна практика - сімейна медицина i стоматологія.

Запропоноване нами запитання «Які заходи потрібно запровадити в медичному ВНЗ, щоб покращити підготовку лікарів-інтернів?», дозволило отримати 114 пропозицій.

Найбільш актуальними з них були:

1. Розширити хірургічний підрозділ в університетській клініці, де б студенти могли постійно навчатись, чергувати i навіть оперувати, починаючи з 5-го курсу.

2. Більш активно включати до навчального процесу лекції, з використанням сучасних інформаційних технологій i 3 залученням лекторів інших наукових закладів країни та закордонних університетів (дану пропозицію висловили $72 \%$ опитуваних).

3. Організовувати безкоштовні воркшопи, застосовувати ПОН.

4. Розвивати співпрацю медичного ВН3 3 закордонними клініками із виїздом на практику студентів та лікарів-інтернів за кордон.

5. Ввести жорстку систему контролю за засвоєнням практичних навичок, особливо на клінічних кафедрах.

6. Дозволити лікарям-інтернам самостійно курувати пацієнтів 3 консультуванням з боку викладача.

7. Включити до програми 6-го курсу удосконалення знань з інтерпретації КТ і МРТ.

8. Регулярно інформувати лікарів-інтернів на очних та заочних циклах щодо нових нормативноправових документів в охороні здоров'я 3 відповідних спеціальностей.

9. На клінічних кафедрах ознайомлювати студентів та лікарів-інтернів 3 новими клінічними протоколами лікування з різних нозологій.

10. Надавати змогу лікарям-інтернам працювати 3 сучасною апаратурою (за можливістю).

11. Урізноманітнити забезпечення кафедр відповідними муляжами для отримання практичних навичок.

12. Збільшити кількість годин для опанування практичних навичок особливо по хірургії, акушерству та гінекології, травматології та інтенсивній терапії в умовах стимуляційного центру, починаючи з 4-го курсу.

13. Вирішити питання на державному рівні стосовно можливості проведення маніпуляцій 3 препаратами в патологоанатомічному бюро.

14. Доповнювати програму навчання стоматологів опануванням навиків інноваційних методів протезування.

15. Забезпечити студентів i лікарів-інтернів сучасними підручниками державною мовою в повному обсязі.

Таким методичним підходом забезпечується всебічне вивчення матеріалу, уміння висловлювати свою думку 3 різних аспектів управління медичною галуззю. Даний підхід до навчання, окрім основної програми на післядипломному етапі, направлений на підвищення мотивації, оволодіння курсом соціальної медицини, управління і організації охорони здоров'я. Пропозиції, ідеї, які озвучили лікарі-інтерни, ми обов'язково обговорюємо на зсіданнях кафедри, науково-практичних конференціях, методичних нарадах університету. 


\section{Висновки}

Таким чином, наше тестування підтвердило, що перевагами ПОН $\epsilon$ незалежне, активне, самостійне, цілеспрямоване навчання курсантів, отримання ними навичок роботи в команді, надбання досвіду у вирішенні складних задач, усвідомлення відповідальності за якість власних знань, розвиток комунікативних здібностей, тренування навичок аргументації, напрацювання вміння чути та поважати думки колег.
Досвід використання інноваційних технологій в доі післядипломній освіті лікарів на кафедрі соціальної медицини та організації охорони здоров'я в нашому ВНЗ, а також їх відгуки після завершення навчального циклу дозоляють зробити висновки про доцільність включення курсу соціальної медицини та організації охорони здоров'я у теоретичну і практично підготовку лікарів всіх спеціальностей на етапі інтернатури, а також вміння практично застосовувати ці технології для колективного обговорення проблем трансформації медичної галузі.

\section{Література}

1. Білинська М. М., Радиш Я. Ф., редактори. Державна політика у сфері охорони здоров'я: кол. моногр.: ч. 1. К.: НАДУ; 2013. 396 с.

2. Корнійчук ОП, Нова система охорони здоров'я України та перспективи кадрової політики. Кубійда ВС, Князевич ВМ, Васюк НО, редактори. Матеріали щоріч. Всеукр. наук.-практ. конф. за між нар. участю. Кадрова політика у сфері охорони здоров’я в умовах загроз національній безпеці України; 2017 бер. 23; Київ. К.: ТОВ «ДСК-Центр»; 2017, c. $67-70$. 2014. 143 c.

3. Черешнюк ГС. Організаційні основи загальної практики - сімейної медицини. Донецьк: Заславський О. Ю.;

4. Черешнюк ГС. Проблемні питання підготовки лікарів загальної практики-сімейної медицини в період реформування в пілотному регіоні. Сучасні медичні технології. 2013; 2(18): 125-128.

5. Комарницька НТ, Ігнащук ОВ, Малачкова НВ, Запровадження інтерактивних методів навчання на циклах тематичного вдосконалення керівників охорони здоров'я. Тези доповідей навчально-методичної конференції. Сучасні методичні технології керування навчальним процесом у вищих медичних навчальних закладах; 2018, с. 76-78.

\section{References}

1. Bilynska M. M., Radysh Ya. F. (2013), Derzhavna polityka u sferi okhorony zdorovia [Public health policy]: kol. monohr.: ch. 1. K.: NADU; 396 p.

2. Kornijchuk, O. P.(2017), "New health care system in Ukraine and perspectives of personnel policy", Materialy schorichnoi Vseukrains'koi naukovo-praktychnoi konferentsii za mizhnarodnoiu uchastiu [Materials annually and All-Ukrainian scientific and practical conferences on international participation], Schorichna Vseukrains'ka naukovo-praktychna konferentsiia za mizhnarodnoiu uchastiu [Annual All-Ukrainian Scientific and Practical Conference on International Participation], Kyiv, Ukraine, pp. 67-70.

3. Chereshniuk HS. (2014), Orhanizatsiini osnovy zahalnoi praktyky - simeinoi medytsyny [Organizational basics of general practice - family medicine]. Donetsk: Zaslavskyi O. Yu.; 143 p.

4. Chereshniuk HS. (2013), Problemni pytannia pidhotovky likariv zahalnoi praktyky-simeinoi medytsyny v period reformuvannia v pilotnomu rehioni. Suchasni medychni tekhnolohii [Problematic issues of training GPs in the pilot region. Modern medical technologies], vol. 2(18), pp.125-128.

5. Komarnytska NT, Ihnashchuk OV, Malachkova NV, (2018), «Introduction of interactive teaching methods on cycles of thematic improvement of health care managers», Tezy dopovidei navchalno-metodychnoi konferentsii. [Thesis of the educational-methodical conference]. Modern methodological technologies of management of educational process in higher medical schools, Kyiv, Ukraine, pp. 76-78.

Дата надходження рукопису до редакції: 13.01.2020 p.

Мета - поширити досвід використання інноваційних методів освіти в до- і післядипломній підготовці керівників охорони здоров'я (директорів, заступників директорів, медичних директорів) на факультеті післядипломної освіти та під час навчання лікарів-інтернів різних спеціальностей.

Матеріали та методи. Матеріалами стали: результати тренінгу «Техніка номінальної групи», засвоєного під час стажування в Літньому інституті UAB (м. Бірмінгем, штат Алабама, США), а також використання методики «Проблемно-орієнтовного навчання» (ПОН), опанованої в рамках проекту «BIHSENA» - «Поєднання Інновацій, Здоров'я і Суспільств: освітній розвиток потенціалу в сусідніх районах Східної Свропи», очолюваного Маастрихтським університетом. 
Результати засвідчили ефективність і доцільність використання в до- і післядипломній освіті методики «Техніки номінальної групи» і ПОН при визначенні і обговоренні актуальних проблем, трансформації системи охорони здоров'я в умовах впровадження БПР (безперервного професійного розвитку). Ці методики розвивають навички вільного, демократичного висловлювання власної думки і аргументів з різних аспектів управління медичною галуззю, будувати комунікації для роботи в команді.

Ключові слова: інноваційні технології, освіта, охорона здоров’я.

Цель - распространить опыт использования инновационных методов образования в до- и последипломной подготовке руководителей здравоохранения (директоров, заместителей директоров, медицинских директоров) на факультете последипломного образования и при обучении врачей-интернов различных специальностей.

Материалы и методы. Материалами стали: результаты тренинга «Техника номинальной группы», усвоенного во время стажировки в Летнем институте UAB (г. Бирмингем, штат Алабама, США), а также использование методики «Проблемно-ориентированного обучения» (ПОО), освоенной в рамках проекта «ВIHSENA» - «Сочетание Инноваций, Здоровья и Обществ: образовательное развитие потенциала в соседних районах Восточной Европы», возглавляемого Маастрихтским университетом.

Результаты показали эффективность и целесообразность использования в до- и последипломном образовании методики «Техники номинальной группы» и ПОО при определении и обсуждении актуальных проблем, трансформации системы здравоохранения в условиях внедрения НПР (непрерывного профессионального развития). Эти методики развивают навыки свободного, демократического высказывания собственного мнения и аргументов по различным аспектам управления медицинской отраслью, строить коммуникации для работы в команде.

Ключевые слова: инновационные технологии, образование, здравоохранение.

Purpose - to broaden the experience of using innovative methods of education in pre- and postgraduate training of health care managers (directors, deputy directors, medical directors) in the faculty of postgraduate education and in the training of interns of various specialties.

Materials and methods. The materials were: the results of the training "Nominal Group Technique", acquired during an internship at the UAB Summer Institute (Birmingham, Alabama, USA), as well as the use of the "Problem Oriented Learning" (POL) methodology, learned in the framework of the BIHSENA project - "Combining Innovation, Health and Societies: Educational Capacity Development in Neighboring Eastern Europe", led by Maastricht University.

The results testified to the effectiveness and expediency of using the techniques of "Nominal Group Technique" and POL in pre- and postgraduate education in identifying and discussing urgent problems, transformation of the health care system in the conditions of implementation of CPD (continuous professional development). These techniques develop the skills of free, democratic expression of their opinions and arguments on various aspects of managing the medical industry, and build communication for teamwork.

Key words: innovative technologies, education, healthcare.

Конфлікт інтересів: відсутній.

Conflicts of interest: authors have no conflicts of interest to declare.

\section{Відомості про авторів}

Черешнюк Галина Семенівна - Заслужений лікар України, старший викладач кафедри соціальної медицини та організації охорони здоров'я Вінницького національного медичного університету імені М.I. Пирогова; вул. Пирогова 56, м. Вінниця, 21018.

+380 (97) 480-75-85, galinamakeeva47@ukr.net.

Комарницька Наталія Тимофіївна - кандидат медичних наук, доцент, зав. курсами післядипломної освіти організаторів охорони здоров’я кафедри соціальної медицини та організації охорони здоров'я Вінницького національного медичного університету імені М.І. Пирогова; вул. Пирогова 56, м. Вінниця, 21018.

+380 (98) 814-55-39, natakomarvinmed@gmail.com. 